\title{
PHYSICS RESEARCH BY THE AUSTRALIAN COMMONWEALTH SCIENTIFIC AND INDUSTRIAL RESEARCH ORGANIZATION
}

\begin{abstract}
HE annual reports of the Divisions of Metrology, Physics and Tribophysics of the Commonwealth of Australian Scientific and Industrial Research Organization covering the year 1960-61 are issued separately*. The Division of Metrology reports a busy year in all sections, but rostriction of activities because of difficulties encountered in staff recruitment and of available workshop facilities. The interferometry section concentrated its efforts on work associated with the optical definition of the metre, and precise studios have been made of the spectral quality of various radiations under consideration as possible primary optical standards of length, the measurement of wave-lengths and wave-length shifts, and the transfer from wave-length standard to mechanical lengths standards. A report on this work was made at the Eleventh Genoral Conference of Weights and Measures in October 1960. The Division's mechanical length standards are now ostablished in terms of the new fundamental unit of the wave-longth of krypton-86 orange light adopted by the Conference. In the Electronics Section the application of a moiré fringe system to replace the mochanically contracting style and scale in the equip. ment for the measurement of periodic errors in machines has been considered and some experimental work has been carried out on electronic circuits to simulate sensory processes. No progress has been made in the applied mechanies section with the provision for a primary standard for force, but new proving equipment has been obtained to augment the Section's range of such devices as proving rings. The theoretical and experimental study of vibration isolation has continued, and much activity is reported in engineering design analysis, including the preparation of instruction manuals and the organization of lectures for design staffs.

In addition to its responsibilities for the maintenance and dovelopment of standards of physical measurement in the fields of heat, light, viscometry and hygrometry, the Division of Physics has made important advances in three major research activi-

* Commonwealth of Australia. Commonwealth Scientific and Industrial Rescarch Organization. Division of Metrology Annual Report for year ending June 30, 1061. Pp i +146 . Jivision of Tribo-

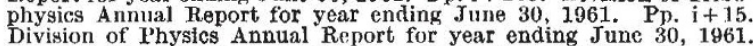
Division of Physies Annual Report for year ending June 30, 1961.
Pp. iv + 25. (Melbourne, Sydney, Canberra, Adelaide, Camden: Pp.iv + 25. (Mel
\end{abstract}

ties. Using techniques developed in the Division of Electrotechnology for the inter-comparison of capacitors, investigations of thermal expansion of various solids have been made down to liquid helium temperatures, enabling the electronic contribution to be measured for the first time. A simple method of zero-ficld paramagnetic resonance spectromotry has been developed and applied to sapphire and a number of paramagnetic salts, and the $\frac{1}{8} \AA$. birefringence filter has been used to study the vertical velocity distribution over extended regions of the solar chromosphere. Developments of now instruments have included a sensitive triodo flame ionization detector for use in gas chromatography, a Fabry-Perot interferometer with plates which are servo-controlled for parallelism, and a stellar seeing-monitor.

The Division of Tribophysies had its origin as a group studying war-time problems of friction and lubrication, but it has extended its investigations to include fundamental studies in the physics and chemistry of surfaces of solids and in metal physics. In most of tho experiments large single crystals are usod, and since clean metal surfaces are highly reactive two ultra-high vacuum systems (to pressures down to $10^{-10}$ torr) have been constructed in association with equipment for following surface reactions by means of a mass spectrometer. The 'atomically flat' surface obtained when a crystal is cut by a plane consists of flat areas separated by monatomic steps. The distribution of such steps and of kinks on the edges of the steps for any crystal cut by a plane in an arbitrary direction has been calculated and models construeted of a surface. Two effects caused by bombarding metal crystals with inert gas ions are being studied. Work has continued on the determination of arrays of dislocations in metals and on the electrical resistivity of dislocations. The results of measurements of stored cnergy and electrical resistivity have been used to calculate the resistivity of a dislocation in aluminium, coppor, nickel and alpha brass. The resistivity of a dislocation was found to increase as the stacking fault energy decreased, but the magnitude of the increase did not suggest that stacking faults make a major contribution to resistivity.

All three reports include lists of staff and of their published papers.

\section{THE NATIONAL INSTITUTE OF OCEANOGRAPHY, WORMLEY}

T HE annual report of the National Ocoanographic Council* describes the work carried out by the National Institute of Oceanography during the year which ended on March 31, 1961. With improved recruitment of staff, tho number in the scientific and experimental officer grades reached nearly 50, with about 60 supporting staff. The Institute's research vessel, R.R.S. Discovery II, remained in full commission throughout the year, working on a wide

* Annual Report of the National Oceanographic Council, 1 April, 1960-31. March, 1961. Pp. v $+41+6$ plates. (Cambridge: At the University Press, 1962.) $5 s$. net. variety of projects, some cruises being joint ventures with other bodies, including the Universities of Birmingham, Bristol and Cambridge. Discovery II is rapidly approaching the end of her working life, and during the year under revicw much time was devoted to the design of a replacement. Since March 1961, the construction of the new ship has, in fact, been put in hand, and it is expected that she will be completed this autumn.

The research activities of the National Institute of Occanography are aimed primarily at a better 
understanding of the physical and biological processes taking place in the sea. It is possible, in a review, to mention only a fow highlights of the work being carried out. In pursuit of basic research on the generation of waves, a wave-recording buoy for use in the open ocean has been developed. It enables observations to be obtained by which the properties of the waves can be related to the structure of the wind flow over them. This work has a direct bearing on new theories of wave generation which have been put forward recently. Internal waves, which reach their greatest amplitude at an interface, or a region of steep density gradient some distance below the sea surface, are the subject of a new theoretical and observational study. Their presence becomes apparent in the vertical oscillations of isotherms, for example, or in movements of a sound-scattering layer.

Oceanic circulation continued to be one of the main fields of activity for the Institute, and a joint project was undertaken with the Woods Hole Oceanographic Institution, on deep-water movements in the Atlantic, near Bermuda. From observations extending over a number of months, it was found that the currents at $2,000 \mathrm{~m}$. and $4,000 \mathrm{~m}$. were both stronger and more variable than had been anticipated. The cause of such transient currents, with a timescale of several weeks, has not yet been established, although possible theories are being considered. A variety of methods, including echo-sounding, horizontal echo-ranging and photography have been used in studies of the sea floor, in both shallow water and deep oceanic areas. In collaboration with the Department of Geodesy and Geophysics, University of Cambridge, the deeper structure of the ocean floor in the region of the mid-Atlantic ridge was investigated by magnetic and gravimetric surveys.

The increasing use of measurements of electrical conductivity as a means of inferring the distribution of density and salinity in the ocean has led to an international investigation being initiated of the relationship between these three properties. The Institute is taking part in this work, which also involves an examination of the relative proportions in which the major chemical constituents occur in sea-water from various regions.

On the biological side, the productivity of oceanic waters has continued to be one of the main fields of interest, and various instruments and techniques have been developed for studying light as a factor in production. One of the findings in the work on the distribution of organisms is that while some species appear closely dependent on the physical conditions in the water masses and on their movements, others show a marked independence of their physical environment. Research has continued on the lifecycles and population dynamics of whales and the application of the knowledge obtained to conservation problems.

The Institute continued to be directed by Dr. G. E. R. Deacon with Dr. N. A. Mackintosh as deputy director, in charge of the biological activities. Dr. J. N. Carruthers, well known for his work in physical oceanography, particularly on currents, retired from the post of assistant director on reaching the age limit, but continued to serve the Institute in a dis. established position.

Plans for the future growth of the Institute have been put forward in accordance with the recommendations of a conference held under the auspices of the Royal Society in November 1960. The National Oceanographic Council considers that an increase in real effort of 50 per cent during the quinquennium 1962-67 should be aimed at, involving the recruitment of 18 scientific staff and 40 in other grades. This would depend on the income being made available to meet a corresponding increase in the expenditure on the Institute and its research ship, which in the year 1960 61 amounted to $£ 283,000$. K. F. BowDEN

\title{
A BIOLOGICAL PRINCIPLE AND ITS CONVERSE: SOME IMPLICATIONS FOR CARCINOGENESIS
}

\author{
By P. R. J. BURCH* \\ Health Physics Division, Oak Ridge National Laboratoryt, Oak Ridge, Tennessee
}

\begin{abstract}
COMATIC mutations of one kind or another have often been suspected of contributing to carcinogenesis, and some recent evidence favours this view ${ }^{1,2}$. A variety of multi-stage mathematical models has been built on this basic supposition to account for the dependence on age of cancer mortality-rates ${ }^{3}$.

Epidemiological evidence points to a marked inherited component in the rtiology of many malignancies, including leukrmia ${ }^{4-6}$.

If the 'inherited component' can be equated with a (nuclear) gene mutation-and the commonest suggestion from the literature is of dominant inheritance with low penetrance-then if we assume a continuity of genetic information from the zygote to any nucleated somatic cell in the mature organism,

* On one year leave of absence from the Medical Research Council Environmental Radiation Research Unit, Department of Medical Physics, University of Leeds, until August 1962
$\dagger$ Operated by Union Carbide Nuclear Company for the U.S. Atomic Energy Commission.
\end{abstract}

it is difficult to avoid the following generalization and its converse:

(1) Where the ætiology of a given neoplasm involves somatic nuclear gene mutations, individual tumours of this kind will be found in which inherited mutations have substituted for somatic.

The converse principle should be valid:

(2) Where Mendelian inheritance of a neoplasm can be demonstrated, somatic mutation should also contribute to its genesis.

Exceptions to (1) can be imagined. Thus a particular allele present in a small proportion of cells may be tolerated in one type of tissue (to contribute to its ultimate malignant transformation), but distributed widely in another organ the same allele may have immediate lethal consequenees. Inheritance of this specific mutation will therefore yield a non-viable karyotype, but arising de novo in an appropriate somatic cell, it could be carcinogenic. It is also 